\title{
Conjugated linoleic acid (CLA) content and fatty acids composition of muscle in rats fed isomers of CLA and selenium*
}

\author{
M. Czauderna ${ }^{1}$, J. Kowalczyk, K.M. Niedźwiedzka, I. Wąsowska \\ and B. Pastuszewska
}

\author{
The Kielanowski Institute of Animal Physiology and Nutrition, \\ Polish Academy of Sciences \\ 05-110 Jabłonna, Poland
}

(Received 5 January 2004; accepted 14 January 2004)

\begin{abstract}
The aim of the study was to determine the influence of conjugated isomers of linoleic acid (CLA) and/or selenium (Se) on the body mass gain of rats, feed intake, and the levels of CLA isomers and some other fatty acids in the femoral muscle. Rat diets enriched in Se, the trans-10,cis-12 isomer and mixtures of the CLA isomers (regardless Se supplementation) tended to decrease body mass gain compared with control rats, while simultaneously supplementation with Se and the trans-10,cis-12 isomer resulted in the highest increase. A mixture of CLA isomers and/or Se supplementation, and the trans-10,cis-12 isomer decreased feed intake, whereas the cis-9,trans-11 isomer, regardless of Se supplementation, only slightly influence of feed intake. Enriching diets with CLA isomers increased their level in muscles as well as the level of non-CLA isomers containing conjugated double bonds (CD). In rats receiving simultaneously Se and mixtures of the CLA isomers or individual CLA isomers the CLA isomers and CD levels in muscles were higher compared with rats fed only the CLA isomers. Rats fed individual isomers or their mixture showed minute changes in C8:0 and C10:0 concentrations in muscles, while the $\mathrm{C} 12: 0, \mathrm{C} 14: 0, \mathrm{C} 16: 0$ and $\mathrm{C} 18: 0$ contents were generally lower. A small increase in C10:0 and C16:0 content was found in rats fed the trans-10,cis-12 isomer. Supplementing Se to diets enriched in CLA isomers usually resulted in an increase in the saturated fatty acid content in muscles in comparison with rats fed only CLA isomers. The linoleic acid content in muscles was enhanced by the Se supplemented diets enriched in the trans-10,cis-12 isomer or in the $2 \%$ CLA isomer mixture, although $1 \%$ mixture of the CLA isomers or the cis-9,trans-11 isomer dosed simultaneously with Se also increased the level of linoleic acid, albeit insignificantly. The Se supplemented diet enriched
\end{abstract}

\footnotetext{
${ }^{*}$ Supported in part by the State Committee for Scientific Research, Grant No. 3 PO6Z 03422

${ }^{1}$ Corresponding author: e-mail: m.czauderna@ifzz.pan.pl
} 
in the trans-10,cis-12 isomer or $2 \%$ mixture of the CLA isomers produced the highest increase of $\gamma$-linolenic acid, the total fatty acid and polyunsaturated fatty acid content in rat muscle.

KEY WORDS: conjugated isomers of linoleic acid, non-CLA conjugated fatty acids, fatty acids, femoral muscles, selenium, rats

\section{INTRODUCTION}

Conjugated linoleic acid (CLA) is a mixture of geometric and positional isomers of linoleic acid in which the double bonds are conjugated (Gnädig et al., 2001). Numerous CLA isomers are possible depending on the position of the double bond pairs (e.g., 7-9, 8-10, 9-11, 10-12) (Corino et al., 2002). The geometrical configuration of the double bonds can also vary to increase the number of possible isomers: trans-trans, cis-trans, trans-cis and cis-cis. CLA isomers are present mainly in ruminant animal fat and dairy products, and are formed as a result of microbial biohydrogenation (Bauman et al., 2003). The major CLA isomer in food products from ruminants is cis-9,trans-11, although other CLA isomers are present and these may vary under different rumen conditions (Griinari et al., 1997). CLA isomers are reported to have varied beneficial health effects, including anticarcinogenic activity, protection against cholesterol-induced atherosclerosis, reduction of body fat, and have been shown to possess immuno-modulating properties (Sebedio et al., 1999; Gnädig et al., 2001). The enrichment of animal products in CLA has therefore become an important objective of animal nutrition. The role of specific CLA isomers has not been clearly established, the most physiologically active being cis-9,trans-11 and trans-10,cis-12 octa-decadienoic acids, involved in lipid metabolism (Sebedio et al., 1999; Alasnier et al., 2002; Evans et al., 2002). Moreover, early studies using rats found that the content of some PUFA was positively correlated with the selenium (Se) concentration in diets (Crespo et al., 1995). Indeed, seleno-cysteine has been found to be an integral part of the active site of glutathione peroxidases as well as phospholipid hydroperoxide glutathione peroxidase (Wolffram, 1999; Zagrodzki et al., 2000). Interestingly, recent studies have established that phospholipid hydroperoxide glutathione peroxidase interferes more directly with protecting PUFA from peroxidation damage (Crespo et al., 1995). Thus, this protective effect of dietary Se (essential component of glutathione peroxidases) on the deposition of CLA isomers and other fatty acids in the body of mammals may also be plausible.

Therefore, the objective of this study was to assess the effects of feeding a mixture of CLA isomers, the cis-9,trans-11, or the trans-10,cis-12 isomer, without or with $\mathrm{Se}(\mathrm{VI})$ supplementation, on feed intake, body mass gain and the levels of CLA isomers, non-CLA fatty acids containing conjugated double bonds, and some saturated and polyunsaturated fatty acids in the femoral muscles of rats. 


\section{MATERIAL AND METHODS}

\section{Animals and diets}

The experiment was performed on young female rats (Wistar, Ifz:BOA). Ten groups of eight rats at 8 weeks of age and $200 \mathrm{~g}$ initial body mass, were for whole experimental period (five weeks) housed individually in plastic cages at a constant temperature $\left(22 \pm 1^{\circ} \mathrm{C}\right)$ with $12 \mathrm{~h}$ light-dark cycle and relative humidity of $50-60 \%$. For one week (adaptation period) the experimental animals were fed a standard diet, Labofeed (Pastuszewska et al., 2000), given at a submaintenance level (daily $9 \mathrm{~g}$ of diet per rat) to reduce their body mass $(\sim 7 \%)$. Then they were for four weeks fed ad libitum the Labofeed diet enriched with a CLA isomer mixture at levels of 0,1 and $2 \%$, isomer cis-9,trans-11 or trans-10, cis-12 at a $1 \%$ level (Table 1). All diets were unsupplemented $\left(_{-\mathrm{Se}}\right)$ or supplemented $\left(_{+\mathrm{Se}}\right)$ with $2 \mathrm{ppm}$

\section{TABLE 1}

Initial body mass of rats ${ }^{1}$ and composition of the experimental diet enriched in the CLA isomers and $\mathrm{Se}\left(\mathrm{as}_{2} \mathrm{SeO}_{4}\right)$

\begin{tabular}{|c|c|c|c|}
\hline Group & $\begin{array}{l}\text { Average body } \\
\text { mass of rats, } g^{1}\end{array}$ & Supplement & Concentration \\
\hline 1 (control group) & $184.9(8)$ & - & - \\
\hline $2+\mathrm{Se}$ & $185.3(8)$ & $\mathrm{Se}$ & $2 \mathrm{ppm}$ \\
\hline 3 & $184.4(7)$ & CLA isomer mixture $^{2}$ & $1 \%$ \\
\hline 4 & $185.6(7)$ & cis- 9, trans-11 isomer $(c 9, t 10)^{2}$ & $1 \%$ \\
\hline 5 & $184.4(7)$ & trans-10,cis-12 isomer $(t 10 c 12)^{2}$ & $1 \%$ \\
\hline 6 & $183.3(7)$ & CLA isomer mixture & $2 \%$ \\
\hline \multirow{2}{*}{$3_{+\mathrm{Se}}$} & $181.9(7)$ & $\mathrm{Se}$ & $2 \mathrm{ppm}$ \\
\hline & & CLA isomer mixture & $1 \%$ \\
\hline \multirow[t]{2}{*}{$4_{+\mathrm{Se}}$} & $184.2(7)$ & $\mathrm{Se}$ & $2 \mathrm{ppm}$ \\
\hline & & cis- 9 ,trans-11 isomer $(c 9, t 11)$ & $1 \%$ \\
\hline \multirow[t]{2}{*}{$5_{+\mathrm{Se}}$} & $183.8(7)$ & $\mathrm{Se}$ & $2 \mathrm{ppm}$ \\
\hline & & trans-10,cis-12 isomer $(t 10, c 12)$ & $1 \%$ \\
\hline \multirow[t]{2}{*}{$6_{+\mathrm{Se}}$} & $182.8(7)$ & $\mathrm{Se}$ & $2 \mathrm{ppm}$ \\
\hline & & CLA isomer mixture & $2 \%$ \\
\hline
\end{tabular}

\footnotetext{
${ }^{1}$ body mass of individually adapted rats after one week of submaintenance feeding (in parenthesis - number of rats in a group). Initial body mass of rats did not differ statistically differ among group at the $\mathrm{P}<0.1$ level

${ }^{2}$ the composition of the mixture of the CLA isomers: $t 11, t 13-2.9 \% ; t 10, t 12-5.1 \% ; t 9, t 11-4.3 \% ; t 8, t 10$ - 2.9\%; $c 11, t 13$ - 13.4\%; $c 10, t 12-28.0 \% ; c 9, t 11-28.6 \% ; c 8, t 10-9.6 \% ; c 11, c 13-1.6 \%, c 10, c 12$ $-1.5 \% ; c 9, c 11-1.4 \% ; c 8, c 10-0.7 \%$. The composition of the $c i s-9$,trans-11 and trans- $10, c i s-12$ isomers - $100 \%$ of $c 9, t 11$ and $t 10, c 12$ isomer, respectively (no other fatty acids were detected). The composition was assessed using $\mathrm{Ag}^{+}$-HPLC system I (Czauderna et al., 2003) and HPLC system II (Czauderna and Kowalczyk, 2002)
} 
Se given as $\mathrm{Na}_{2} \mathrm{SeO}_{4}$. After a 4-week experimental period the rats were killed by $\mathrm{CO}_{2}$ and their femoral muscles were removed and weighed.

\section{Reagents and chromatographic equipment}

HPLC grade acetonitrile and n-hexane were purchased from Lab-Scan (Ireland), other reagents were of analytical grade (POCh, Poland). A CLA isomer mixture (95-97\%), and isomers cis-9,trans-11 (95-97\%) and trans-10,cis-12 (95-97\%) were supplied by Larodan Fine Chemicals AB (Sweden), while sodium selenate $\left(\mathrm{Na}_{2} \mathrm{SeO}_{4}\right)$ and all fatty acid standards were provided by Sigma (USA).

A Waters (USA) HPLC 625LC system for fractionation of the underivatized CLA isomers was used. The system comprised a 515 pump, a 712 WISP autosampler and a 2487 dual $\lambda$ absorbance detector. The ion-exchange columns loaded with silver ions $\left(\mathrm{Ag}^{+}\right)$used were two $250 \times 4.6 \mathrm{~mm}$ Chrompac ChromSpher $5 \mu \mathrm{m}$ Lipids columns (The Netherlands) in conjunction with a $10 \times 3 \mathrm{~mm}$ guard column. The underivatized CLA isomers and unidentified species containing conjugated double bonds were determined according to Czauderna et al. (2003).

The derivatized fatty acids in muscle samples were determined according to Czauderna and Kowalczyk (2002). The instrument used consisted of an Alliance separation module (model 2690, Waters) and a Waters 996 photodiode array detector (HPLC system II). All derivatized saturated, unsaturated non-conjugated fatty acids were detected at $256 \mathrm{~nm}$, while derivatized CLA isomers and non-CLA fatty acids containing conjugated double bonds were monitored at 234 and $256 \mathrm{~nm}$ (Czauderna and Kowalczyk, 2001, 2002). UV spectra of the eluate with a spectral resolution of $1.2 \mathrm{~nm}$ were obtained every second and were electronically stored on a computer hard disk. Separations of derivatized fatty acids were performed on two Nova Pak $\mathrm{C}_{18}$ columns $(4 \mu \mathrm{m}, 250 \times 4.6 \mathrm{~mm}$ I.D., Waters) in conjunction with a Waters guard column (Czauderna and Kowalczyk, 2002).

\section{Preparation and hydrolysis of samples}

Muscle samples collected from experimental rats were frozen, lyophilized and the obtained residues were stored in sealed tubes at $-20^{\circ} \mathrm{C}$ until analysed. Muscle samples $(\sim 45 \mathrm{mg})$ were hydrolysed with $3.5 \mathrm{ml}$ of $2 \mathrm{M} \mathrm{NaOH}$ at $80-85^{\circ} \mathrm{C}$ for 30 min (Heinig et al., 1998; Czauderna and Kowalczyk, 2001). The hydrolysates were acidified with $4 \mathrm{M} \mathrm{HCl}$ to $\mathrm{pH} \sim 2$ and then free fatty acids were extracted four times with $4 \mathrm{ml}$ of dichloromethane. The lower organic layer was dried with $\mathrm{Na}_{2} \mathrm{SO}_{4}(\sim 100 \mathrm{mg})$ and then the organic solvent was removed under a stream of argon (Heinig et al., 1998; Czauderna and Kowalczyk, 2001). Afterwards the residue (I) was used for derivatization as below or re-dissolved in $1 \mathrm{ml}$ of dichloromethane and then $30 \mu \mathrm{l}$ of the resulting solution were injected onto the ion-exchange co- 
lumns ( $\mathrm{Ag}^{+}-\mathrm{HPLC}$ system I). The mobile phase of $1.6 \%$ acetic acid and $0.0125 \%$ acetonitrile in n-hexane was chosen as the optimum mobile phase for fractionation of underivatized fatty acids containing conjugated double bonds (Czauderna et al., 2003). Analyses were performed by the isocratic elution program (flow-rate of 1 $\mathrm{ml} / \mathrm{min}$ ) and UV detection at $234 \mathrm{~nm}$ (the column temperature $25^{\circ} \mathrm{C}$ ).

\section{Derivatization procedures}

To a residue (I) in a reacti-vial, $0.5 \mathrm{ml}$ of dibromacetophenone $(48 \mathrm{~g} / \mathrm{L}$ in acetone) and $60 \mu \mathrm{l}$ of triethylamine were added. The resulting solution was mixed again and reacted for $30 \mathrm{~min}$ at $40^{\circ} \mathrm{C}$ (Czauderna et al., 2002). Then, the processed samples were injected onto $\mathrm{C}_{18}$-Nova Pak columns (HPLC system II) (Czauderna and Kowalczyk, 2002). For analysis of all derivatized fatty acids in standards and biological samples, the binary gradient elution program was used (Table 2). Injections volumes were 5-20 $\mu \mathrm{l}$. The maximum pressure of HPLC systems was $38.5 \mathrm{MPa}$. Fatty acid derivative peaks were identified by the retention time of processed standards injected separately and by adding standard solutions to biological samples. Moreover, saturated fatty acids were differentiated from conjugated fatty acids and non-conjugated unsaturated fatty acids by the use of a photodiode array detector.

TABLE 2

Gradient elution program $^{1}$ used for separation of derivatized fatty acids (HPLC system II)

\begin{tabular}{cccc}
\hline $\begin{array}{c}\text { Time } \\
\min \end{array}$ & $\begin{array}{c}\text { Flow rate } \\
\mathrm{ml} / \mathrm{min}\end{array}$ & \multicolumn{2}{c}{ Composition, $\%^{2}$} \\
acetonitrile & water \\
\hline 5.0 & 2.4 & 68.0 & 32.0 \\
23.0 & 2.4 & 76.5 & 23.5 \\
34.5 & 2.7 & 85.0 & 15.0 \\
80.9 & 2.7 & 85.0 & 15.0 \\
81.0 & 3.0 & 100.0 & 0 \\
$100.0^{3}$ & 3.0 & 100.0 & 0 \\
\hline
\end{tabular}

${ }^{1}$ separations were performed at the columns temperature of $37^{\circ} \mathrm{C}$

${ }^{2}$ all changes of mobile phase composition were linear

${ }^{3}$ after $100 \mathrm{~min}$ the columns were re-equilibrated for $10 \mathrm{~min}$ in $68 \%$ solvent $\mathrm{A}$ and

$32 \%$ solvent $\mathrm{B}$ at a flow rate $2.4 \mathrm{ml} / \mathrm{min}$

\section{Statistical analyses}

Statistical analyses of the effects of the CLA isomers or Se were conducted using the non-parametric Mann-Whitney $U$ test for comparing independent experimental groups, while statistical analyses of the simultaneous the CLA isomers and Se treatments (Groups $3_{+\mathrm{Se}}, 4_{+\mathrm{Se}}, 5_{+\mathrm{Se}}$ and $6_{+\mathrm{Se}}$ ) were performed applying two- 
factorial analysis for comparison with the independent control group I. The Excel 2000 and Statistica (ver. 6) programs were used for the statistical analyses.

\section{RESULTS AND DISCUSSION}

During the preliminary period of submaintenance feeding on the control unsupplemented diet, all rats lost about $15 \mathrm{~g}$ body mass. The greatest differences in feed intake among the experimental diets were found during the first two weeks of ad libitum feeding. Feed intake tended to decrease as the CLA isomer mixture level increased in both Se-supplemented $\left(_{+\mathrm{Se}}\right)$ and unsupplemented diets (Table 2). These data indicated that rats fed diets containing Se and the 1 or $2 \%$ dietary CLA isomer mixture showed a similar effect on feed intake, however, the addition of $2 \%$ CLA isomer mixture with or without Se (Group 6 and $6_{+\mathrm{Se}}$ ) most efficiently decreased total feed intake $(\mathrm{P}<0.05)$. Supplementation of the diet with only the trans-10, cis-12 isomer significantly decreased $(\mathrm{P}<0.01)$ feed intake during the first week of the study, although no significant decrease was observed after a longer experimental time. On the Se-supplemented diet enriched with the trans10,cis-12 isomer, this difference was smaller and limited to the first week of the experiment. Interestingly, it has been found that the cis-9,trans-11 isomer in the diet (Group 4) tended to increase total feed intake, although the presence of $\mathrm{Se}$ in the diet enriched in this isomer (Group $4_{+\mathrm{Se}}$ ) insignificantly reduced total feed intake compared with the control rats (Group 1).

The effects of experimental factors on rat body mass gain were rather small, but some interactive effects of CLA isomers and Se supplementation were observed. As can be seen from Table 3, feeding mixtures of the CLA isomers (Groups 3 and 6), the trans-10, cis-12 isomer (Group 5), or Se (Group $2_{+\mathrm{Se}}$ ) to rats tended to decrease body mass gain compared with control rats (Group 1). These results are supported by several other studies (Sebedio et al., 1999; Bauman et at., 2003), which have indicated that the trans-10,cis-12 isomer, due to its geometric and positional structure, is the most potent CLA isomer in terms of antiobesity activity, thus, efficiently reduced feed intake and body mass gain (Group 5). It was surprising that supplementation of the diet enriched only in Se (Group $2_{+\mathrm{Se}}$ ) tended to slightly decrease feed intake and most efficiently reduced body mass gain. Therefore, it seems reasonable to assume that $2 \mathrm{ppm}$ of Se in the diet is responsible for the lowest feed conversion efficiency.

It has not been clearly established which specific CLA isomers are responsible for the various biological effects, however; the cis-9,trans-11 isomer is thought to play the key role in the antiatherogenic and anticarcinogenic activities (Corino et al., 2002; Bauman et al., 2003). As expected, therefore, the cis-9,trans-11 isomer supplied to the diet (Group 4) had no influence on body mass gain, while the pre- 


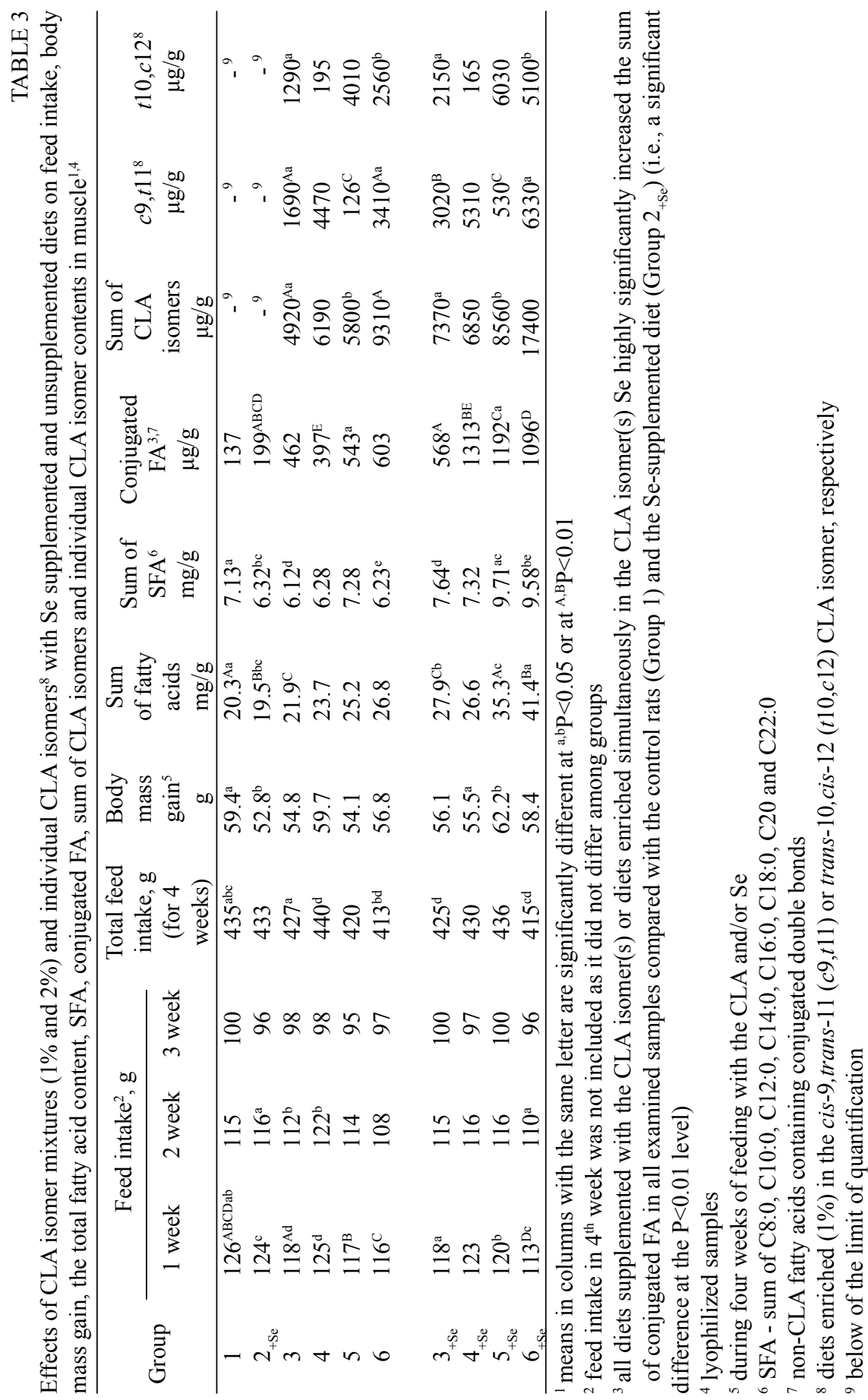


sence of this isomer in the Se-supplemented diet insignificantly counteracted the decrease of body mass gain from the Se dose (i.e. compare Groups $4_{+\mathrm{Se}}$ and 2). Interestingly, one of the most prominent effects of all CLA isomers is reduction of the negative influence of $\mathrm{Se}$ in the diet (see Group $2_{+\mathrm{Se}}$ ) on rat body mass gain. Furthermore, the simultaneous presence of Se and 1 or $2 \%$ mixture of the CLA isomers (Groups $3_{+\mathrm{Se}}$ and $6_{+\mathrm{Se}}$ ) insignificantly elevated body mass gain compared with rats fed diets enriched in only mixtures of the CLA isomers (Groups 3 and 6). It was also found that the Se supplemented diet enriched in the trans-10,cis-12 isomer (Group $5_{+\mathrm{Se}}$ ) produced the highest increase in rat body mass gain $(\mathrm{P}<0.05)$. It seems likely that the interaction between Se and the trans-10,cis-12 isomer or its metabolites (Group $5_{+\mathrm{Se}}$ ) resulted in the most efficient increase in body mass gain (Table 3) and the most effective decrease in energy expenditure.

Exhaustive chromatographic investigations (using HPLC system II) have demonstrated that unidentified non-CLA fatty acids containing conjugated double bonds (CD) in femoral muscles had retention times of $23.2 \pm 0.3,24.8 \pm 0.3$, $38.3 \pm 0.4$ and $40.3 \pm 0.4$ min (Czauderna and Kowalczyk, 2002). Therefore, we suggest that these fatty acids containing conjugated double bonds (CD) contained more than two double bonds because of their shorter elution times compared with the retention times of the CLA isomers. In fact, all CLA isomers eluted as six peaks and appeared at around 49-55 min of a HPLC run (Czauderna and Kowalczyk, 2002). The results of earlier studies Banni et al. (1999) and Sebedio et al. (1999) also seem to support our above assumption. Moreover, Gnädig (2002) reported that Wistar rats fed a CLA isomer mixture for one month revealed the presence of conjugated fatty acids: C18:2 (cis-6,cis-9,cis-11 C18:3 and cis-6, trans-10,cis12 C18:3), C20:3 (cis-8,cis-11,trans-13 C20:3 and cis-8,trans-12,cis-14 C20:3) and C20:4 (cis-5,cis-8,cis-11,trans-13 C20:4 and cis-5,cis-8,trans-12,cis-14 C20:4). Recent data on this subject also reinforces the finding that CLA isomers could be metabolized in vivo into long-chain conjugated PUFA (elongation and desaturation products of CLA) using the same pathway as linoleic acid. Similarly, our experiment clearly demonstrated that the concentration of conjugated fatty acids (CD) in muscles is always significantly higher in rats fed the CLA isomers compared with muscle of the control rats (Groups 1) and rats fed only Se (Group $\left.2_{+\mathrm{Se}}\right)$. Thus, we suppose that these CD are mainly metabolites of CLA isomers (Igarashi and Miyazawa, 2000), hence the very high band in the spectral range from 215 to $245 \mathrm{~nm}$ (possess the absorbance maximum at $234 \mathrm{~nm}$ ) due the presence of conjugated double bonds (Czauderna and Kowalczyk, 2001, 2002) and a weaker band at longer UV wavelengths possessing the absorbance maximum at $256 \mathrm{~nm}$ due to derivatization of the assayed fatty acids with dibromacetophenone (Czauderna and Kowalczyk, 2001, 2002). Therefore, in the current study we could successfully investigate the effect of experimental diets on the muscle content of total CD (Table 3). The study showed that the level of CD in the femoral muscle 
of the control rats (Group 1) was very low, while a small, insignificant increase was found in the muscle of rats fed Se (Group $2_{+\mathrm{Se}}$ ). As expected, the mixtures of the CLA isomers or individual isomers with or without Se treatment resulted in a significant increase $(\mathrm{P}<0.01)$ in the concentration of $\mathrm{CD}$ in muscles compared with the control rats (Group 1) and rats fed only Se (Group $2_{+\mathrm{Se}}$ ). Interestingly, this study is unique in that it shows that animal diets simultaneously enriched in Se and the CLA isomers, have the major impact on CD and CLA isomer contents in muscles. In fact, addition of Se to the diets enriched in CLA isomers resulted generally in elevated concentrations of CD and the CLA isomers in muscles, moreover, the highest significant increase $(\mathrm{P}<0.01)$ of $\mathrm{CD}$ was found in rats fed the diet containing the cis-9, trans-11 isomer and Se (Group $4_{+\mathrm{Se}}$ ). A possible explanation may be that Se added to the experimental diets stimulated the yield of CLA isomers metabolizing into long-chain PUFA containing conjugated double bonds using the same pathway as linoleic acid.

The increase of a level of the mixture of the CLA isomers in the dietary induced a significant rise $(\mathrm{P}<0.05)$ of the CLA isomers content in muscles (compare Groups 3 and 6), the concentration of the sum of all CLA isomers being approximately three times greater than the cis-9,trans-11 or trans-10, cis-12 isomer (Table 3 ). The response to the mixture of the CLA isomers was substantially greater on Se supplemented diets than on Se unsupplemented ones. Feeding both individual isomers increased the concentration of the CLA mixture in rat muscles to a similar extent, and also enhanced the concentration of the respective isomer. Moreover, the response to the trans-10,cis-12 or the cis-9,trans-11 isomer, similarly as to the CLA isomer mixture (1 or $2 \%$ ), was far greater on Se supplemented diets than on Se unsupplemented ones. The observation that addition of Se to experimental diets increased the CLA isomer content in muscles is consistent with results concerning the level of $\mathrm{CD}$ in rat muscles. These results reinforce the hypothesis that the increase in CLA isomer (substrate) concentration in the rat body stimulated the yield of the CLA isomers metabolizing into long-chain PUFA containing conjugated double bonds (CD). In fact, the cis-9,trans-11 and trans-10, cis-12 isomers, like linoleic acid, are substrates for $\Delta^{6}$ - and $\Delta^{5}$-desaturases, therefore, after feeding a mixture of the CLA isomers, conjugated eicosateraeoic acids were found in rat liver (Gnädig et al., 2001).

As can be seen from results (Tables 3 and 4), all experimental diets fed to rats resulted in several changes in the saturated fatty acid (SFA) and PUFA compositions of muscles. Rats fed individual CLA isomers or their mixture showed minute changes in C8:0 and C10:0 concentrations in muscles, while C12:0, C14:0, C16: 0 and $\mathrm{C} 18: 0$ concentrations were generally lower, although a small, insignificant increase in C10:0 and C16:0 content was observed in rats fed the trans-10,cis-12 isomer supplemented diet (Group 5). These data together demonstrated that the CLA isomer mixture (1 or 2\%) in the rat diet tended to reduce MUFA and SFA in 


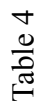

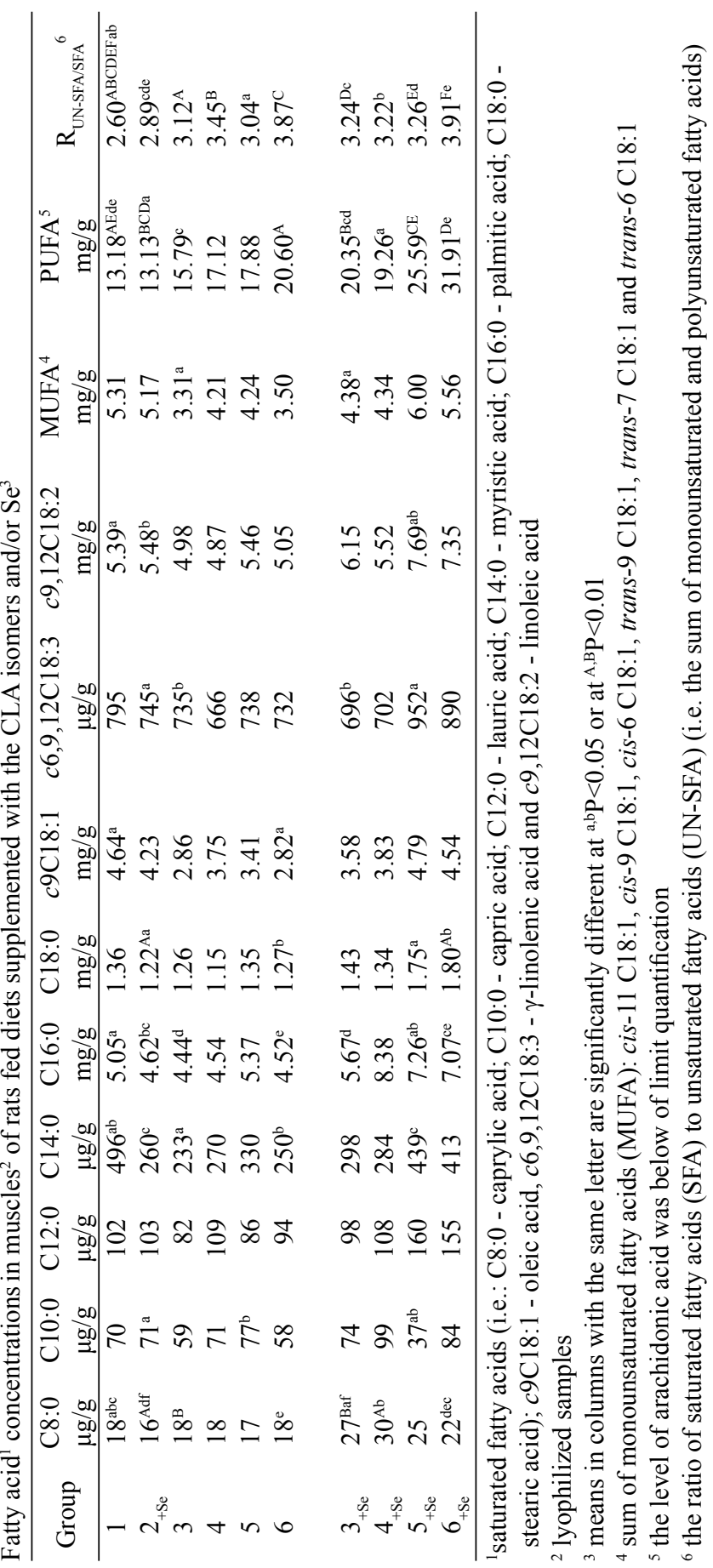


muscle, especially saturated fatty acids containing from 10 to 18 carbon atoms, most probably due to an increase in the rate of lipolysis and enhanced fatty acid $\beta$-oxidation of fatty acids in skeletal muscles of experimental animals fed the mixture of the CLA isomers (Park et al., 1997; Alasnier et al., 2002). Interestingly, diets enriched in $2 \%$ mixture of the CLA isomers (Group 6) significantly $(\mathrm{P}<0.05)$ decreased oleic acid (cis-9C18:0) content in muscles, while cis-9 C18:0 tend also to be lower in muscles of rats fed $1 \%$ mixture of the CLA isomers and individual isomers (Groups 3, 4 and 5). Considering these results we suggest that the CLA isomers and especially $2 \%$ mixture of the CLA isomers cause also a reduction of $\Delta 9$-desaturase capacity (Simon et al., 2000; Loor and Herbein, 2003). Surprisingly, the addition of Se to the diets enriched in the CLA isomers (Groups $3_{+\mathrm{Se}}, 4_{+\mathrm{Se}}$, $5_{+\mathrm{Se}}$ and $6_{+\mathrm{Se}}$ ) generally resulted in increased SFA and total fatty acids contents in muscles in comparison with the control rats (Group 1) and rats fed only CLA isomers (Groups 3, 4, 5 and 6; Tables 3 and 4). In general, the above findings confirm the synergic effect of the diets enriched simultaneously in Se and the CLA isomers on the accretion yield of SFA (Table 3) and PUFA (Table 4) in rat muscles. As can be seen from the data summarized in Table 4, diets containing Se and the mixture of the CLA isomers (Groups $3_{+\mathrm{Se}}$ and $6_{+\mathrm{Se}}$ ) or Se and the trans-10,cis-12 isomer (Group $5_{+\mathrm{Se}}$ ) more efficiently increased the concentrations of caprylic, lauric, myristic, palmitic, stearic acids and cis-9 octadecenoic acid (oleic acid) and PUFA in muscles compared supplementing a single CLA isomer (Groups 3,6 and 5). This effect could be related to the decreased yield of fatty acid $\beta$-oxidation of fatty acids and to diminishing the ability of the CLA isomers, especially trans-10,cis12 (Sébédio et al., 1999; Alasnier et al., 2002) to inhibiting of $\Delta^{9}$-desaturase activity (e.g., palmitoyl-CoA or stearoyl-CoA desaturase), when rats fed diets enriched simultaneously in Se and the CLA isomers. As expected, in our study $\gamma$-linolenic acid and linoleic acid concentrations in muscles also tended to enhance by feeding simultaneously Se and the trans-10,cis-12 isomer or $2 \%$ mixture of the CLA isomers (Groups $5_{+\mathrm{Se}}$ and $6_{+\mathrm{Se}}$ ) compared with the control rats (Group 1) and rats fed the CLA isomers (Groups 5 and 6).

The finding that the CLA isomers fed to animals increased the level of CLA isomers, $\mathrm{CD}$ and other PUFA in the muscles of rats and increased the value of the ratio of saturated fatty acid to unsaturated fatty acids $\left(\mathrm{R}_{\mathrm{UN} \mathrm{SFASFA}}\right)$ (Table 4$)$ is valuable for nutritionists in the context of research to improve the nutritional quality of meat of monogastric farm animals for human health. Interestingly, Se in the diets enriched in the CLA isomers more efficiently elevated the level of CLA, $\mathrm{CD}$, PUFA, as well as, the value of $\mathrm{R}_{\mathrm{UN} \text { SFA/SFA }}$ compared with the diets enriched in only the CLA isomers, so, extra Se in the diets possessing the CLA isomers can be more effectively improved the nutritional quality of meat. 


\section{CONCLUSIONS}

The trans-10,cis-12 isomer and the CLA isomer mixture induced a decrease in body mass gain and feed intake, while the cis-9,trans-11 isomer did not visibly change body mass accretion or feed intake in rats. The present study demonstrated that the simultaneous dietary supplementation of Se and the trans-10, cis-12 isomer or the CLA isomer mixture had a beneficial effect on accumulation of the trans-10,cis-12 isomer and the CLA isomer mixture in the muscle. Feeding rats with both Se and the cis-9,trans-11 isomer had slightly synergetic effect on the level of the cis-9,trans-11 isomer in the muscle. It can be hypothesized that the interaction between Se and the trans-10,cis-12 isomer, the mixture of CLA isomers or their metabolites exerts the greatest protective effect against peroxidation damage and/or catabolism on these isomers. Finding that Se and some selected CLA isomers fed to animals considerably increase the level of CLA isomers, non-CLA fatty acids containing double bonds and other PUFA in muscles of animals is valuable information for nutritionists carrying out research to improve the nutritive value of food for human health.

\section{REFERENCES}

Alasnier C., Berdeaux O., Chardigny J.M., Sébédio J.L., 2002. Fatty acid composition and conjugated linoleic acid content of different tissues in rats fed individual conjugated linoleic acid isomers given as triacylglycerols. J. Nutr. Biochem. 13, 337-345

Banni S., Angioni E., Casu V., Melis M.P., Carta G., Corongiu F.P., 1999. Decrease in linoleic acid metabolites as a potential mechanism in cancer risk reduction by conjugated linoleic acid. Carcinogenesis 20, 1019-1024

Bauman D.E., Griinari J.M., Corl B.A., 2003. Nutritional regulation of milk fat synthesis. Annu. Rev. Nutr. 23, 203-227

Chouinard P.Y., Corneau L., Barbano D.M., Metzger L.E., Bauman D.E., 1999. Conjugated linoleic acids alter milk fatty acid composition and inhibit milk fat secretion in dairy cows. J. Nutr. 129, $1579-1584$

Corino C., Mourou J., Magni S., Pastorelli G., Rosi F., 2002. Influence of dietary conjugated linoleic acid on growth, meat quality, lipogenesis, plasma leptin and physiological variables of lipid metabolism in rabbits. J. Anim. Sci. 80, 1020-1028

Crespo A.M., Reis M.A., Lanca M.J., 1995. Effect of selenium supplementation on polyunsaturated fatty acids in rats. Biol. Tr. Elem. Res. 47, 335-341

Czauderna M., Kowalczyk J., 2001. Separation of some mono-, di- and tri-unsaturated fatty acids containing 18 carbon atoms by high-performance liquid chromatography and photodiode array detection. J. Chromatogr. B 760, 165-178

Czauderna M., Kowalczyk J., 2002. HPLC separation of some unsaturated and saturated fatty acids. Chem. Anal. (Warsaw) 47, 867-882

Czauderna M., Kowalczyk J., Niedźwiedzka K.M., Wąsowska I., 2002. A highly efficient method for derivatization of fatty acids for high performance liquid chromatography. J. Anim. Feed Sci. 11, 517-526 
Czauderna M., Kowalczyk J., Wąsowska I., Niedźwiedzka K.M., 2003. Determination of conjugated linoleic acid isomers by liquid chromatography and photodiode array detection. J. Anim. Feed Sci. 12, 369-382

Evans M.E., Brown J.M., McIntosh M.K., 2002. Isomer-specific effects of conjugated linoleic acid (CLA) on adiposity and lipid metabolism. J. Nutr. Biochem. 13, 508-516

Gnädig S., 2002. Conjugated linoleic acid (CLA): effect of processing on CLA in cheese and the impact of CLA on the arachidonic acid metabolism. PhD. Thesis, Fachbereichs Chemie der Universität Hamburg, INRA, Unité de Nutrition Lipique, Dijon (France)

Gnädig S., Rickert R., Sébédio J.L., Steinhart H., 2001. Conjugated linoleic acid (CLA): physiological effects and production. Eur. J. Lipid Sci. Tech. 103, 56-61

Heinig K., Hissner F., Martin S., Vogt C., 1998. Separation of saturated and unsaturated fatty acids by capillary electrophoresis and HPLC. Amer. Lab. May, 24-29

Igarashi M., Miyazawa T., 2000. Do conjugated eicosapentaenoic acid and conjugated docosahexaenoic acid induce apoptosis via lipid peroxidation in cultured human tumor cells? Biochem. Biophys. Res. Commun. 270, 649-656

Loor J.J., Herbein J.H., 2003. Reduced fatty acid synthesis and desaturation due to exogenous trans10, cis12-CLA in cows fed oleic or linoleic oil. J. Dairy Sci. 86, 354-1369

Park Y., Albright K.J., Liu W., Storkson J.M., Cook M.E., Pariza M.W., 1997. Effect of conjugated linoleic acid on body composition in mice. Lipids 32, 853-858

Pastuszewska B., Ochtabińska A., Morawski A., 2000. A note on the nutritional adequacy of stock diets for laboratory rats and mice. J. Anim. Feed Sci. 9, 533-542

Sébédio J.L, Gnädig S., Chardigny J.M., 1999. Recent advances in conjugated linoleic acid research. Curr. Opin. Clin. Nutr. Metab. Care 2, 499-506

Simon O., Männer K., Schäfer K., Sagredos A., Eder K., 2000. Effects of conjugated linoleic acids on protein to fat proportions, fatty acids, and plasma lipids in broilers. Eur. J. Lipid Sci. Tech. $102,402-410$

Wolffram S., 1999. Absorption and metabolism of selenium: differences between inorganic and organic sources. In: T.P. Lyons, K.A. Jacques (Editors). Biotechnology in the Feed Industry. Nottingham University Press, Nottingham, pp. 547-566

Zagrodzki P., Bik D., Fitak B.A., Suchocki P., Niemczuk K., 2000. Selenoenzymes in animal tissues after supplementation with selol. Bull. Vet. Inst. Puławy 44, 215-220 


\section{STRESZCZENIE}

\section{Zawartość sprzężonych izomerów kwasu linolowego (CLA) oraz innych kwasów tluszczowych w mięśniach szczurów żywionych dietami z dodatkiem izomerów CLA i selenu}

Celem pracy było zbadanie wpływu izomerów sprzężonego kwasu linolowego (CLA) lub/i selenu (Se) na wzrost szczurów, pobranie paszy oraz poziom izomerów CLA i innych kwasów thuszczowych w mięśniu udowym. Diety z dodatkiem Se, izomeru trans-10,cis-12 oraz mieszaniny izomerów CLA (bez względu na obecność Se) zmniejszają masę ciała szczurów w porównaniu z grupą kontrolną, natomiast największy przyrost masy zwierząt uzyskuje się po podaniu diety zawierającej jednocześnie izomer trans-10,cis-12 i Se. Podanie mieszaniny izomerów CLA i/lub Se, izomeru trans-10,cis-12 zmniejsza pobranie paszy, natomiast cis-9,trans-11 bez względu na obecność Se ma znikomy wpływ na spożycie. Dodatek izomerów CLA do diety zwiększa ich stężenie w mięśniach, jak również poziom innych kwasów tłuszczowych zawierających podwójne sprzężone wiązania (CD). Obecność Se $\mathrm{w}$ diecie zawierającej mieszaninę izomerów CLA lub indywidualne izomery zwiększa stężenie izomerów CLA, nasyconych kwasów thuszczowych oraz CD w mięśniach w porównaniu ze szczurami otrzymującymi jedynie izomery CLA. Mieszanina i indywidualne izomery tylko nieznacznie wpływają na poziom C8:0 i C10:0 w mięśniach, natomiast zmniejsza się stężenie C12:0, C14:0, C16: 0 i C18:0. Niewielki wzrost stężenia C10:0 i C16:0 stwierdzono w mięśniu szczurów, którym podano izomer trans-10,cis-12. Zawartość kwasu linolowego w mięśniach zwiększa dieta wzbogacona w Se oraz mieszaninę lub indywidualne izomery CLA. Obecność Se w diecie zawierającej trans-10,cis-12 lub 2\% mieszaniny izomerów CLA przyczynia się do największego wzrostu zawartości kwasu $\gamma$-linolowego, PUFA oraz sumy wszystkich kwasów tłuszczowych w mięśniu szczurów. 